\title{
STORY MAPPING STRATEGY TO IMPROVE STUDENTS' READING SKILL AT SMP AN-NUR WATUKOSEK PASURUAN
}

\author{
Zakiya Isnani \\ zakiya86isnani@gmail.com \\ STT Gempol Walisongo
}

\begin{abstract}
The main purpose of this research is to know the improvement of students' reading skill in narrative text through story mapping strategy. this research was conducted at SMP An-Nur Watukosek-Pasuruan. this research is a classroom action research which is conducted in two cycles. this study was carried out on February to April 2021. the subjects were the eight grade students of SMP An-Nur Watukosek, Pasuruan. The data collection involved a number of instruments, namely preliminary test to know the reading ability firstly. Then, using post-test in the end of each cycle, questionnaires, and also an interview. The post-test used in each cycle to know the reading's improvement after using story mapping strategy. The questionnaire in the form administrated to collect data about the students' appreciation in learning reading using story mapping, both the teacher's method, the students, and also story mapping itself. There were several steps in this research implementation, they are identifying the problems, planning, acting, observing and reflecting.the result showed that the students' reading ability improved and the target of this research was achieved. And also they felt easier to understand the text, because it consist of some elements, are orientation, complication, and resolution.
\end{abstract}

Keywords: Story mapping, reading skill

\section{INTRODUCTION}

Every aspect of life involves reading. Every day we always encounter text from functional text like road sign, restaurant menu, product labels, and informative text lie school textbooks to pleasurable ones like short stories and novels. This is in accordance with Rivers (1981:259) who states that the most important activity in any language class is reading. Reading is not only a source of information and a pleasurable activity, but also a means of consolidating one's knowledge of a language. In other words, reading activities can bring many benefits for students such as to get information, pleasure and knowledge. Therefore, teaching reading in the classroom should be interesting and can cause students to be enjoyed and pleasure in the learning experience.

For the most students, especially for the students at eight grades of Junior high School, mastering reading is one of the 
most important skills of learning a second language. The main goal is not only reading the text but also comprehending the reading texts. Therefore, the teacher should use an alternative way to teach narrative, is using story mapping.

While Narrative is a text the purpose of which is to entertain, create, stimulate emotion, motivate, and teach the reader. Narrative is text which have kinds story (folktale, fable, legend, short story, etc). The Narrative text has general structure pattern, i.e.: (1) orientation, (2) complication, (3) resolution, coda/ending. The structure pattern of narrative text can be explained as runaway story from narrative text, beginning from orientation until the story the end or how ending from the story.

A narrative text begins with orientation, which gives information about character in the story (who), and the setting of time (when) and place (where). The orientation functions to introduce to reader about the background of the story. The middle of the narrative text is organized around the plot. The plot includes a series of events that are written by author to hold our attention and build excitement as the story progresses. The plot contains (1) initiating events, the event that starts the main character off on a series of events to solve the problem, (2) a series of events in which main character attempts to solve the problem.

Concerning with story mapping itself, a story map is a graphic representation of all parts of the elements of a story and the relationship between them (Davis and McPherson 1989 in Burns 1999). So, when we talk about story map, we will talk about story elements and story grammar because the essence of the map is the organizations of that elements.

Wright (2003) affirms that story mapping is a procedure which train students to recognize the basic framework of 
narrative stories in order to improve their comprehension of a text. Then, Voorhis (2008) states story mapping refers to organizational tool for summarizing the character, setting, and plot of a work of literature. The purpose of story map of course is to help students focus on the important elements of narrative theme, characters, setting, problems, plot events, and resolution and on the relationship among those elements. Voorhis (2008) states story mapping refers to organizational tool for summarizing the character, setting, and plot of a work of literature. The purpose of story map of course is to help students focus on the important elements of narrative theme, characters, setting, problems, plot events, and resolution and on the relationship among those elements.

As one graphic organizer, story mapping may share the benefits of the graphic organizers in common such as: 1) these organizers are a way encourage students to think about information in new ways. With graphic organizers, you remove the words and focus on the connections. 2) They are a great tool for activities that ask students to review concepts and demonstrate their understanding. 3) They can easily make changes and take different perspectives, in other words, it helps students clarify their thinking. 4) It can be used as a nice planning tool from information identification to product development. 6) They are great for visual thinkers or those that need to practice their visual thinking.

There are some previous studies which related to this research. The first is the research has done by Fadmiwati (2011) with the tittle "Improving the Reading Ability of the second Grade Students of SMPN 1 Paiton Through the Implementation of story Mapping" and the second is the research has done by Dwiretno (2008) with the tittle "Using Story Mapping through Cooperative 
Learning to Improve the Eight Graders

Reading Ability of SMP Negeri 4 Malang. University of Malang”.

Based on the two previous studies above, it can be seen that both researchers were the proof that story mapping is a good strategy in teaching reading especially in teaching reading narrative text in order the students' reading skill could be improved.

To be more specific, the advantages of the teaching narrative by using story mapping strategy in three stages of reading activities namely pre reading, whilst reading and post reading will be discussed as follows: in pre reading activity, story map is beneficial to: 1) provide the framework that direct interrelated information such as setting, characters, problems, goal, action and outcome (Rathvon, 1999), 2) enhance the students' ability to predict and set purpose for reading (Almasi, 2003:134).
In Whilst Reading, it is possibly to:

1) provide students a concrete framework for identifying the elements of narrative stories, be cognitive tools that focus attention and enhance the students' ability to monitor incoming information and compare it to earlier prediction, 3) enable the story elements to be easily recognized and demonstrated (Alagozlju), 4) lead the students to better comprehension so they become more involved and take greater interest in the details of the story (classroom-resources, online), 5) immerse students into thinking because each details of the story can be easily visualized, 6) leads students to focus on distinctive features of a story, 7) explore the reading process by breaking that process into component part and making the students aware of the way that these part combine (Margaret Foley), 8) help students to organize information and ideas.

While in post reading story mapping can 1) enhance comprehension and recall of 
narrative text, 2) give guidance for students to retell or summarize the story.

The goal of teaching reading is comprehending the text. Learners should be able to make themselves understood, using their comprehending to know implicit and explicit meaning from the text. From this view, I conclude that reading is not only read the text but also comprehend the text, implicit and explicit meanings.

\section{RESEARCH METHOD}

Based on the focus of the research, this research intends to improve the students' reading skill using the strategy of story mapping. the researcher used collaborative action research model that suggested by Kemmis and Taggar, which designed planning, actuating, observing (gathering and analysing the data), and reflecting (Burns, 2009, p. 9). this is called "collaborative" because the researcher collaborated with his collaborator in conducting this research.

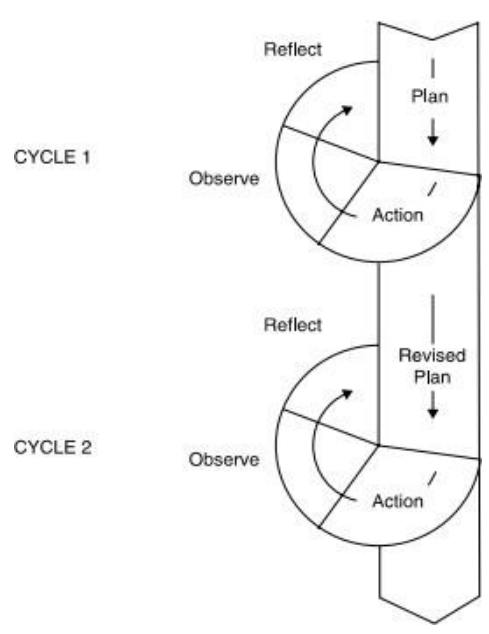

Figure 1: The Cyclical Action Research model based on Kemmis and Mc Taggart (1988).

The subjects of this research were the eight grade students of SMP An- Nur Watukosek- Pasuruan academic Year 2020-2021. The research implemented for two months, start from February until April 2021.

The researcher conducted this research into two cycles and every cycle has 4 steps. It was based on Kemmis and Taggart model. They are: Planning, acting, observing and reflecting (making conclusion and research report).

\section{Planning}

In this step, the researcher and the collaborator prepared the guided questions 
through inside outside circle to be implemented in learning teaching activity. It consisted of the strategy, lesson plan, and criteria of success.

Preparing a suitable strategy. The strategy of story mapping that applied in the classroom as follow.

Firstly, the teacher activated the students' prior knowledge, shared the example of narrative text and connected the topic with the students' background knowledge, explained the objective of the lesson and the topic. Besides, the teachers gave the story map layout. The purpose of the activity was to give basis for the students to deal with their own text.

Secondly, the teacher was supposed to read or model the text so that the students could follow the class. The teacher asked them to define the difficult words and guide them to identify the elements of the story.
While in the third process is the teacher was focused on having the students comparing the students' work and the content of the story. Related to this activity, it was planned that the teacher invited one to 3 students to share the result of their work in front of the class. It was expected that in this activity the students were able to participate in the class discussion and to give a comment and response. And the last activity was giving the students' comprehension test (post test).

Designing the lesson plan. The lesson plan focused on the use of story mapping strategy in the classroom to solve the students' problems in reading. The topics discussed in this cycle are legend narrative and humor narrative.

Criteria of success. The criteria of success implemented in this study is students' achievement of reading English ability are $75 \%$ of the students get the score of greater than or equal to 75 of the range. 
the strategy has been successful or not.

\section{Implementation}

When all preparations are ready to use, the researcher implemented the activities have been designed using story mapping strategy. The subject is the eight grades' students of SMP An-Nur Watukosek - Pasuruan.

In implementing the action plan, the researcher was assisted by collaborator who at the same time acted as the observer in the teaching and learning process in the class. During the process, a collaborator held field-notes and observation check list.

\section{Observation}

In this phase, the researcher observes the activities which were happening during the teaching and learning process. The researchers write all of the activities in the observation notes relate to the teaching and learning process.

\section{Reflection}

$$
\text { Reflection is conducted to }
$$

determine whether the implementation of
During reflecting, the researcher and the collaborator discusses together the implementation and observation of the teaching and learning process in the classroom. From the result of observation, the researcher and the collaborator analyse the students' improvement in the previous action. And also, the researcher makes two kinds of conclusion: the conclusion of each cycle and the final one.

The data were in the form of qualitative and quantitative data. The qualitative data were about the students' participation in reading class. The quantitative data were students' reading test. The data were obtained from the students and the collaborating teacher. Instrument and techniques for data collection.

In analyzing test, there are three formulas used: First, the researcher finds out the average score of students. Second, He tries to get the percentage of students 
who has passed the standard minimum criterion (KKM: 70). Third, He identifies the improvement of students score after treatment.

The formula by (Sudijono, 2014, p. 43):

$\mathrm{p}=\frac{f}{N} \times 100 \%$

$\mathrm{p} \quad=$ The class percentage

$\mathrm{f} \quad=$ Total percentage score

$\mathrm{N} \quad=$ Number of cases

To collect the required data, the researcher used a field-note, questionnaires, and a test reading (posttest). The field notes were used regularly to take notes and record the information about the event, dates, and persons involved in the teaching and learning process. While questionnaire is used to know the reason and the comment about teaching and learning reading through story mapping strategy from the students.

FINDINGS AND DISCUSSION
In implementing this

research, there were some factual data

which have found in several activities.

It will be described below:

Before implementing the story mapping media in teaching reading, the researcher conducted an observation and some interview through a preliminary study in order to identifying the problem, the researcher found some problems during the English lesson on Eight grade of SMP An Nur Watukosek - Pasuruan. In fact, the teaching learning process was not effective. Most of the students just keep silent when the teaching learning process was running on. They seldom asked to the teacher (passive) if they did not understand about English material. They are afraid to ask to the teacher, the students also lazy to read a text when reading learn. Because of that, the student's score was bad or low. It showed that the learning motivation of the students still low. 
Besides having held an observation and some interviews, the researcher also held a pre - test to measure the basic competence of the students in reading narrative tetxs. according to the result of the pre - test, the data showed that the everage score in the eighth grade of SMP AN - Nur was 69.89. Meanwhile, the English teacher states that the minimum of standard criterion competencies (KKM) of English subject is 75 (seventy Five); It means that was under of KKM. Then, there were only 11 students (17.95\%) who passed the KKM, it means that there were 26 students who need more treatment.

After identifying the problems, the researcher implemented the story mapping media by following the research procedure (planning, acting, observing and reflecting). This research has implemented into two cycles.

\section{Cycle 1}

Based on the result of preliminary study, the researcher with the teacher arranged the planning. the plan was included identification of the problem, planning an action, implementing the action, observing the action, and reflecting on the observation.

During the acting phase, the researcher also conducted the observation. In this case, the observer was the English teacher. Based on that observation there were some positive and negative findings. For example: The lesson was more active and the Teacher came on time (positive findings); Some students felt shy to ask and not paying attention (negative findings).

After the observation, the researcher held test in order to measure the students reading skills after the treatment. the data showed that the students score has incresed but the result was unqualified with the success criterion of classroom action research. the everage score is 76,35 . There were 27 students have passed the KKM. 
The last, the researcher conducted the reflecting phase based on the data that have found in acting and observing phase. Based on the data above, it concluded that the action of cycle 1 was not success enough because the students score was under the criteria. so, the researcher and his collaborator decided to continue the cycle in order to make a better improvement of the students' reading skill and this classroom action research could be succed.

\section{Cycle 2}

Based on the reflection in the cycle

1, the researcher and his collaborators concluded some revisons from the cycle 1 into cycle 2, they are: (1) The teacher must give explanation as simple as possible, (2) The teacher must more firmly in teaching, (3) The teacher must more be covered the class, (4) The teacher must adding some material that were needed. After decided the problems, the researcher and his collaborator planned the next cycle by establishing a lesson plan, planning the media and preparing the material. after the plan was done.

On the other hand, the researcher also conducted some observations during the implementation in each meeting. the observer has found that there were some Improvement in students understanding. It was also proven with the improvement of students score on cycle 2 test. The data showed that the average score of students was 82,29 the percentage of students who passed KKM.

based on the observation, the students score has passed the criterion of success action research. so, the researcher and his collaborators decided to stop the research in reflecting phase.

\section{The Implementation of students' Reading}

\section{Skill by using Story Mapping}

Concerning the data gained from: the questionnaire in the second cycle, it was found that the response of the students 
dealing with the implementation of story mapping strategy was good. In the second cycle, the students were more active to answer the researcher's questions and they were more interested with the lesson. As a result, the student's scores were better than in first cycle.

\section{The Improvement of students' Reading}

\section{Skill by using Story Mapping}

Based on the result of the test above, the student' scores have increased in each cycle. It means that the students reading skills has improved. In the pre-test, the average student scores were only 69,89 , after implementation in the first cycle the average of student scores increased to 76,35 . Then, the average student scores increased again to 82,29. Accordingly, the number of students who passed KKM also increased in each cycle.

Relating to the data gained from the direct interview among the researcher and the students in the second cycle, the students stated that story mapping strategy was interesting because it used a fascinating layout of story map. Story mapping helped the students to comprehend the narrative text easily by identifying the elements of story of narrative text. The students more attracted with the story mapping in the second cycle, they stated that the detail story map helped them to analyse the complication clearly by identifying the initiating events, problems, attempts, and then they could find the resolution and ending. In contrast, most of them got difficulties to find the problems directly when they used story mapping in the first cycle.

\section{The Students' Responses towards Story}

Mapping in Learning Narrative Reading skill

The researcher used reflecting on the observation to analyze the findings which were obtained from the result of the observation, include three criteria of success: field note, reading test (student's scores), and questionnaire. 
Those were supported by the result

of direct interview among the researcher and the students. The researcher investigated her observation in the second cycle based on the data which had collected on the second cycle. Thus, the results of the reflection on second cycle were presented as follows:

1. The result student's attitude was increased during the teaching learning activities such as the eagerness to pay attention, to ask questions, and to answer questions.

2. The student's mean score in the post test of cycle second increased 82.29. It was at the good category.

From the result of the reflection, the researcher concluded that her remedial action on second cycle was successful. All students could pass the minimum of mastery learning and the mean was above $80 \%$.

\section{CONCLUSION}

After being implemented and developed through two cycles, it is concluded that the suitable model of strategy using story mapping in teaching learning reading consists of the following procedures, the first phase was pre reading activities; (1) Explain the objectives, (2) Stimulate the prior knowledge of a story and its elements by asking leading questions (give a model of story map for the first meeting), (3) divide the class into groups of four students, including a range of skill level in each group, (4) Hand out the worksheet and explain the instruction in the worksheet. The second phase was whilst reading; (1) Have the students to read the story, (2) Discuss about unfamiliar words finding in the text, (3) Ask the students to study the text by answering questions based on the text above, (5) Facilitate the group discussion. The last phase post reading; (1) Ask the students to fill the story map, (2) Give feedback on the students' works to 
improve their understanding about the story map.

Based on the findings from the teaching and learning process using story mapping strategy which was done in two cycles, it is concluded that this strategy can improve the progress students' reading comprehension of the eight grade students of SMP An- Nur Watukosek- Pasuruan Academic Year 2020-2021. It also increased the students' participation especially as they worked in group. Their opinion toward story mapping strategy was also positive.

In accordance with the discussion in previous chapter, it can be summarized that the story mapping is an effective way to increase the students' reading ability especially in comprehend the narrative text. It might be useful as a pre reading, whilst reading, and post reading.

\section{REFERENCES}

Agustina, Iis. 2008. Pembelajaran Teks Narrative. Unpublished paper used as the lecturer material of Curriculum English instrument at state University of Malang.

Alagouzlu, Nurray.n.d. Infusing Graphic Organizers and Short Stories in Language Teaching (online). (http://dergiler.ankara.edu.tr/dergiler 127/755/9626.pdf,retrieved July 7, 2010)

Amer, Aly. A. 1992. The effect of Story Grammar Instruction on the EFL Students' Comprehension of Narrative TEXT. Reading in Foreign Language 8 (2). (online) (2011) (http://nflrc.hawai.edu/rfl.PastIssues/ rfl82amer.pdf.etrieved on January 7

Boulineau; Fore III; Hagan-Burke. 2004. Use of Story-Mapping to Increase the Story-grammar Text Comprehension of elementary Students with Learning Disabilities. Learning Disability Quarterly (online). (http://www.questia.com/googleSch olar.qst?docId=5006815644, retrieved September 15, 2010)

Burns, A. 1999. Collaborative Action Research for English Language Teachers. Cambridge University Pers.

Burns, A. 2009. Doing Action Research in English Language Teaching (A Guide for Practitioners). Routledge. https://doi.org/10.4324/9780203863 $\underline{466}$

Dwiretno, Galuh. 2008. Using Story Mapping through Cooperative Learning to Improve the Eight Graders Reading Ability of SMP Negeri 4 Malang. University of Malang.

Jones, C. Raymond. 2006. Strategies for reading Comprehension accessed at 
2.30 p.m on March 24 $4^{\text {th }}$, (http://www.Readingquest.org/strat/s torymap.html) 2013.

Nuttal, Cristine. 1981. Teaching Reading Skill in a Foreign Language. Heinemann. Sudijono, A. 2014. Pengantar Statistika Pendidikan. Rajawali Pers. 